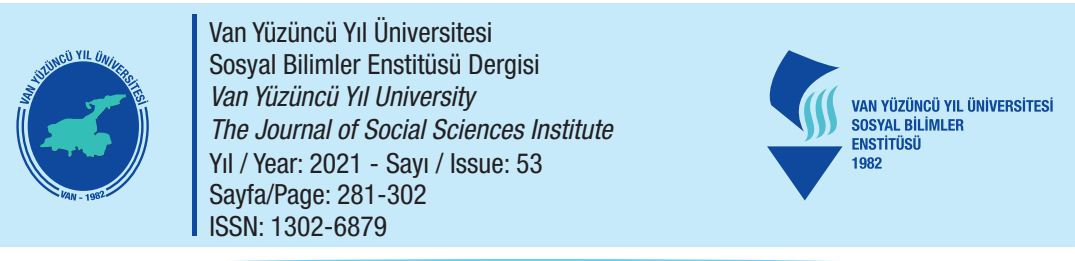

\title{
Üsküdar Hurufat Defterlerine Göre Gebze (Gekboze) Kasabasındaki (Nahiyesindeki) Vakıf Eserleri (1060-1061-1063-1065-1067-1068 Numaralı Hurufat Defterleri) \\ The Üsküdar Hurufat Registers and Foundation Works/Waqfs in the Gebze (Gekboze) District (The Hurufat Registers No: 1060-1061-1063-1065-1067-1068)
}

\section{- Saliha TANIK*}

*Arș. Gör. Dr., Ankara Hacı Bayram Veli Üniversitesi, Edebiyat Fakültesi, Sanat Tarihi Bölümü, Ankara/Türkiye.

Res. Assist. Dr., Ankara Hacı Bayram Veli University, Faculty of Letters, Department of Art History, Ankara /Turkey. saliha.tanik@hbv.edu.tr

ORCID: 0000-0002-5406-2608

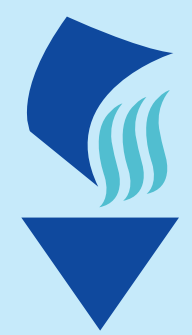

Makale Bilgisi I Article Information Makale Türü / Article Type: Arastırma Makalesi/ Research Article Gelis Tarihi / Date Received: 07/06/2021

Kabul Tarihi / Date Accepted: 24/08/2021

Yayın Tarihi / Date Published: $30 / 09 / 2021$

Atıf: Tanık, S. (2021). Üsküdar Hurufat Defterlerine Göre Gebze (Gekboze) Kasabasındaki (Nahiyesindeki) Vakıf Eserleri (1060-1061-1063-1065-10671068 Numaralı Hurufat Defterleri). Van Yüzüncü YII Üniversitesi Sosyal Bilimler Enstitüsü Dergisi, 53, 281-302.

Citation: Tanık, S. (2021). The Üsküdar Hurufat Registers and Foundation Works/Waqfs in the Gebze (Gekboze) District (The Hurufat Registers No: 10601061-1063-1065-1067-1068).

Van Yüzüncü Yıl University the Journal of Social Sciences Institute, 53, 281-302.

\section{$\ddot{O} \mathbf{z}$}

Sehir tarihi ve şehrin imar faaliyetleri ile ilgili en önemli kaynaklardan biri Vakıflar Genel Müdürlüğü Arşivinde bulunan Hurufat Defterleri'dir. Calışmamızda Gebze nahiyesi ile ilgili olarak Üsküdar Hurufat Defterleri'nin 1060-1068 nolu defter aralığındaki kayıtları okunmuş, Gebze nahiyesinin iktisadi, eğitim ve sosyal durumu ve merkez/köy yerleşimleri hakkında önemli bilgiler tarafımızca tespit edilmiştir. İncelememize konu olan defterler 1705-1789 tarihleri arasını kapsamaktadır. Şehirdeki bilinmeyen yapıları, mescitlerin camiye çevrilmesi ve yapıların bânilerini (yaptıranı) incelediğimiz defterler sayesinde öğrenmekteyiz. Bu bakımdan Hurufat Defterleri Sanat Tarihi disiplinine önemli bir kaynaklık etmektedir. Yaptığımız söz konusu çalışmada nahiyedeki yerleşimlerin 16.yy.'dan günümüze kadar mevcudiyetleri araştırılmış, bir kısmının ad değişikliğine gidildiği bazılarının ise zamanla başka bir bölgeye bağlandığ 1 anlaşılmıştır. Kayıtlara göre, 18.yy.'da Gebze nahiyesinde 20 adet cami, 8 adet mescit, 3 adet zaviye, 3 adet mektep ve 1 adet muallimhâne yapıları bulunmaktadır. Yapılar kendi içinde alt başlıklara ayrılarak ayrı bir tabloda gösterilmiştir. Yapılardaki kurum atamaları ve görevlilerin sayısını belirten tablolar hazırlanmıs ayrıca atama şekilleri, alınan ücretler, kadı veya naip isimleri hakkında bilgiler çalışmamızda belirtilmiştir.

Anahtar Kelimeler: Gebze, hurufat defterleri, vakıf, dini ve sosyal kurumlar. 


\section{Abstract}

The Hurufat Registers in the Archives of the General Directorate of Foundations are important information sources about the history and structures in a city. This study aimed to read the Üsküdar Hurufat Registers of the Gebze district (No: 1060-1061-1063-1065-1067-1068) to gather important information about the economic, educational and social status and village settlements of the region. The registers that are the subject of our study covered the years 1705-1789. Thanks to the registers, we learned about the structures and buildings, the conversion of masjids into mosques, and the funders of the structures. In this respect, Hurufat Registers are primary resources for Art History. It was seen that some locations were renamed, and some were connected to another region in time. According to the registers, there were 20 mosques, eight masjids, three zawiyas, three schools, and one teacher training school (i.e., muallimhâne) in Gebze in the $18^{\text {th }}$ century. The structures were categorized and shown in a table. The official appointments and the number of officers in the institutions were presented in tables, and additional information about the appointment types, wages, and the names of qadi (i.e., kadi) or regent (i.e., naib) was provided in the study.

Keywords: Gebze, hurufat registers, foundation, religious and social institutions.

\section{Giriş}

Osmanlı döneminde bir hayır sahibi ya da devlet eliyle oluşturulan vakıf müessesi, devletin sosyal, kültürel ve dini ihtiyacını belirli gelir ile karşılayan önemli bir hizmet aracı olmuştur. Osmanlı devletinde kurulan vakıflara ilişkin bir kısım vakfiye kayıtlarının yanında vakıf müesseselerine günlük yapılan tayin ve terfi işlemleri Hurufat Defterleri'ne kayıt edilirdi (Çakar, 2018: 22). Anadolu ve Rumeli Kazaskerlik dairesi ruznamçe kalemlerinde tutulan Hurufat Defterleri atik ve cedid olmak üzere iki kısma ayrılmakta olup (Demirtaş, 2012: 51) Anadolu ve Rumeli serisi şeklinde 209 koleksiyondan oluşmaktadır (Alkan, 2010: 825). Kazaskerlik dairesinde tutulan hurufat defterlerindeki atama işlemleri padişah arzıyla hareket veya atama ruznâmçesi adı verilen defterlere geçirilirdi (Beyazit, 2013:44). Anadolu kayıtlarının, 146 tane defterden, Rumeli kayıtlarının ise 63 defterden oluştuğu belirtilmektedir (Demirtaş, 2012: 51). 17.yy. başlarında tutulan hurufat defterlerinin son kayıtları 1839 yılında gerçekleşmiştir (Baykara, 1990: 3-4). Hurufat defterlerinin tutulan atik ve şahsiyet kayıtlarından daha eski olduğu ifade edilmektedir (Muşmal ve İnal 2015:119-120). İlk hurufat defterleri ile 
ilgili yayında, Tuncer Baykara'nın 1142 numaralı defter kayıtlarının transkripsiyonu verilmiştir (Baykara,1990). İlerleyen y1llarda şehir tarihi araştırmalarına kaynaklık edecek birçok sayıda çalışma ortaya konulmuştur (Öntuğ, 1999:149-272; Çal, 2001: 125-166; Ertan, 2005; Yıldız, 2010; Muşmal ve İnal 2015: 119-129; Memiş Eroğlu, 2016:75104; Çakar ve Uzun, 2017; Naldan, 2018: 85-95; Çakar, 2018: 21-41; Naldan, 2020: 115-131).

Hurufat Defterleri, bahsi geçen vakıf eserleri (cami, mescit, türbe, zaviye, tekke, hamam vs.) hakkında tamir bilgisi, yapının o dönemdeki durumu, mescitlerin camiye dönüştürülmesi, bâninin ad ve bilgileri, yapının yer aldığı bölge ve çevresi, bağlı olduğu vakıf ve vakıf işleyişi bakımından Türk Sanat Tarihi açısından da önemli bir kaynaktır.

Vakıflar Genel Müdürlüğü Arşivi'ndeki Üsküdar Hurufat Defterleri'nde Gebze (Gekboze) nahiyesine ait Hicrî 1109 (16971698)- Hicrî Muharrem 1249 (Mayıs-Haziran 1833) tarihleri arasındaki toplam 23 defter bulunmaktadır. Defter kayıtları arasındaki tarihler 536 numaralı deftere kadar belli bir sirayı takip ederken, bu defterden sonra birden 1057 no'lu deftere geçilmiştir. İncelememizde Gebze nahiyesindeki çeşitli vakıf eserlerini konu edinen 1060-1068 numara aralığındaki defterlerinin incelenmesi makale hacmini aşmaması bakımından uygun görülmüsstür. İncelediğimiz defterlerden en erken tarihlisi Hicri Zilhicce 1116 (Mart-Nisan 1705), en geç tarihlisi Hicrî 9 Rebiu'l-ahir 1203 (7 Ocak 1789) kaydıdır. Araştırmamamızda belli numaradaki defterler ele alındığı için tüm vakıf eserleri bulunmamaktadır. Kocaeli'nin bir deprem kuşağında yer alması nedeniyle defterde yer alan yapıların, söz konusu doğal afet nedeniyle günümüze gelemediğini söylemek mümkündür.

İncelediğimiz defterlerde Gebze'deki cami, mescit, mekteb, zaviye ${ }^{1}$, muallimhâne $^{2}$ yapıları ele alınmış olup buradaki görevli kişiler hakkında da bilgi verilmiştir. Bu bakımdan Gebze'nin sosyo-kültürel, dini, idari ve ekonomik bakımından özelliklerini yansıtan Hurufat Defterleri tarihe temel bir kaynak oluşturması bakımından büyük bir önem arz etmektedir. Çalışmamızda, 20 adet cami, 8 adet mescit, 3 adet zaviye, 2 adet mektep ve 1 adet muallimhâne yapısına yer verilmiştir.

\section{Gebze'nin Genel Durumu}

"Dakiviza" kelimesinden türeyen Gebze ismi zaman içinde aldığ 1 çeşitli isimlendirmelerin yanında Gekbuze olarak da adlandırılmıştır

\footnotetext{
${ }^{1}$ Tarikat mensubu dervişlerinin bir şeyh yönetiminde yol ağzı veya yerleşim yerlerinde kaldıkları, yiyecek-içecek ve barınma ihtiyaçlarının ücretsiz olarak karşılandığı yapı veya yapı topluluğudur (Ocak ve Faruki, 1986: 476).

${ }^{2}$ Öğretmen yetiştirmek için kurulan okul (Develioğlu, 2004: 658).
} 
(Yücel, 2018:51). Nitekim şehir, Hurufat Defterleri'nde "Gekboze Nahiyesi/Kasabası" olarak geçmektedir. Gebze 17.yy.'da kadılık bakımından, 18.yy.'da ise kaza dahilinde Üsküdar'a bağlı olduğundan (Çelik, 2003:12) Gebze'deki vakıf eserleri Üsküdar Hurufat Defterleri'ne kayıt edilmiştir. Gebze'nin 16.yy.'da 1522 tarihli kanunnâmeye göre "Yalakabad (Yalova), Görele, İznik, İznikmid (İzmit), Şile, Kandıra, Yoros" (Kaya, 2007: 62) adlı kazaları ile Kocaeli Sancă̆ı'nın kaza merkezi olduğu anlaşılmaktadır. Söz konusu yerleşimde 1530 tarihli tahrire göre 101 köy (Çelik, 2003: 14) 10 mahalle bulunmaktadır (Çelik, 2003: 122). 17.yy.'da yapılan tahrire göre Gebze (Gekboze)'nin köy sayısında 100'ü aşkın olarak artış gözlendiği ve mahalle sayısının aynı oranda kaldığı anlaşılmaktadır (Yurdakul, 2016: 1235). Şehir, 1923 yılında Üsküdar vilâyeti dahilindeyken sonrasında yeniden Kocaeli vilâyetine bağlı kalmıştır (Çelik, 2003:12-14). Günümüzde Gebze, Kocaeli ilinin bir ilçesi durumunda olup İzmit körfezinin kuzeyinde yer almaktadır. Son incelemeye göre Gebze ilçesinin 40 adet mahallesi ve 392 bin civarında nüfusu bulunmaktadır.

İncelediğimiz defterlerde 18.yy.'a ait Gebze (Gekboze) nahiyesine bağl1 23 adet köy, 5 adet mahalle yer almaktadır. Bütün defterler incelenmese bile buradan hareketle 18. yy.'da köy sayısında bariz bir azalma olduğunu söylemek mümkündür. Söz konusu defterlerde de 18.yy.' da Gebze nahiyesine bağlı köylerin zaman içinde Gebze sınırları dışında kaldığı ve başka ilçelere bağlandıkları görülmektedir. Köy adlarına bakıldığında yerleșimlerin Türkçe özellikli adlar tașıdıkları anlaşılmaktadır. Bunlara Çonkara, Depecik, Darıca, Pelidli, Timurcu (Demir), Donuzluca, Tavşanlu vs. köy adları örnek gösterilebilir. Buradan hareketle Gebze (Gekboze) nahiyesinin eski bir Türk yerleşimi olduğunu söylemek mümkündür. Hurufat defterinde 18.yy. tarihli bazı köy ve mahallelerin 16.yy.'dan beri mevcut olduğu ve sonraki dönemlerde de varlıklarını korudukları anlaşılmaktadır (Tablo 1-2).

Çalışmamıza konu olan defterlerde sadece beş yerde vakıf ismi açıkça belirtilmiștir. Sözü edilen vakıflar Darıca Köyü Korucu Mehmed Mescid-i Vakfı, İlyas Bey Vakfı, Tuzla Köyü Hacı Ahmed bin Abdülmennan Nukud- Vakfı, Tavşanlı Köyü Camii Nukud-1 Vakfı ve Karaaliler Köyü Ali bin Hüseyin Camii Nukud-1 Vakfıdır.

\section{Gebze Nahiyesindeki Vakıf Eserleri}

\subsection{Gebze Nahiyesindeki Camiler}

1060-1068 yılları aralığındaki defter kayıtlarına göre 18.yy.'da Gebze'deki camileri tespit etmek mümkün olmuştur. Bu defterlerdeki kayıtlardan camilerin yer aldığı köy ve mahalle adları, kimlerin görevli 
olarak camiye atandığı, kimlerin hangi sebeple görevden alındığı, kimlerin beratlarının yenilendiği veya yeni verildiği, camiyi kimin yaptırdığı, hangi yapıların mescit iken camiye dönüştürüldüğü tespit edilebilmektedir. Tablo 3'te 18.yy.'da belirtilen Hurufat Defterleri'ndeki camilerin yer aldığı köy ve mahalle adları, hangi görevli kadrosuna kaç kez atama yapıldığı defter ve sayfa numarasına göre verilmiştir (Tablo 3). Köy ve mahallelerdeki cami sayısı toplam 20 adettir. Söz konusu camilerden 19 tanesi köy yerleşiminde yer alırken, 1 tanesi mahallede bulunmaktadır. Muallim Köyü Camii, Akviran Köyü Camii ve Tavşanlı Köyü Camii mescit iken daha sonra camiye çevrilmiş yapı örnekleridir. Cami listesine bakıldı̆̆ında geniş bir görevli kadrosunun bulunmadığı anlaşılmaktadır. Bazı camilerde tek bir görevli kadrosunun yer aldığ 1 görülmektedir. İncelediğimiz hurufat defterlerine göre en çok görevli kadrosunun bulunduğu yapılar Tavşanlı Köyü Camii ve Pelitli Köyü Kethüda Mehmed Camii'dir. Diğerlerinden farklı olarak Tavşanlı Köyü Camii ve Karaaliler Köyü Ali bin Hüseyin Camii örneklerinde mütevelli kadroları yer almaktadır. 2 adet caminin bânisi bellidir. Pelitli Köyü Kethüda Mehmed Camii'nin bânisi Kethüda Mehmed Bey iken, Tavşanlı Köyü Camii'nin banisi ElHac Musa Halifedir.

\subsection{Gebze Nahiyesindeki Mescitler}

İncelediğimiz hurufat defterlerinde Gebze nahiyesinde 8 tane mescit bulunmaktadır. Mescitler genelde daha basit yapılar olup mahallelerde konumlanmıştır. Gebze'de 2 tanesi köy yerleşiminde, 4 tanesi mahallede ve 2 tanesi adı belirtilmemiş mahallede mescit bulunmaktadır. Mescitlerde camilere oranla görevli kadrosu daha azdır. Köy ve mahalle mescitlerinde genelde imam kadrosu yer aldığ anlaşılmaktadır. Farklı olarak Darıca Köyü Korucu Mehmed Paşa Mescidi'nde mütevelli kadrosu ve İlyas Bey Mescidi'nde cüzhan ve mütevelli kadrosu bulunmaktadır. İlyas Bey Mescidi'nin evkâf-1 mülhâkadan olduğu ve Haseki Sultanın evkafında yer aldığı anlaşılmaktadır. İki adet mescidin bânisi bellidir. Darıca Köyü Korucu Mehmed Mescidi'nin bânisi Korucu Mehmed, İlyas Bey Mescidi'nin bânisi ise İlyas Bey'dir (Tablo 4).

\subsection{Gebze Nahiyesindeki Eğitim Yapıları}

Gebze Nahiyesindeki eğitim yapıları Sıbyan Mektebi ve Muallimhâne yapı örneklerinden oluşmaktadır. Söz konusu örneklerden 1'i mahalle, 2'si köy yerleşiminde bulunmaktadır. Muallimhâne yapısının bağlı olduğu yer kesin olarak belirtilmemiştir. Eğitim birimlerinde Muallim-i Sibyan namıla mektep hocası görev 
yapmaktadır. Karabakkal Mahallesi mektebinde cami imamının mektep hocalığı da yaptığı anlaşılmaktadır. Buradaki mektebin bânisinin Hoca Ayşe Hatun olduğu belirtilmiştir. Öksüzzâde muallimhânesinin kurucusunun ise Öksüzzâde sıfatlı bir zat olduğu ifade edilmiștir. Tuzla Köyü mektebinin El-Hac Abdülmennan Vakfı ve Öksüzzâde Muallimhânesi'nin ise İlyas Bey Mescidi Vakfi'nın mahsülü olduğu ifade edilmiştir. Ayrıca Tuzla Köyü mektebinin imam olanlar için vakfiyede şart koşularak kurulduğu anlaşılmaktadır (Tablo 5).

\subsection{Gebze Nahiyesindeki Zaviyeler}

İncelediğimiz defterlerde Gebze nahiyesindeki zaviyeler 3 tanedir. Söz konusu yapılardan 2 tanesi köy, 1 tanesi adı belirtilmemiş mahalle yerleşiminde bulunmaktadır. İbrahim Ağa Zaviyesinde bir kişinin birden fazla görevde yer aldığı anlaşılmaktadır. Kutbiddin Zaviyesinin Zaviyedarı Şeyh ve Postnişin, İbrahim Ağa Zaviyesinin Zaviyedarının ise Şeyh olduğu görülmektedir (Tablo 6).

\section{Gebze Nahiyesindeki Vakıf Eserlerin Görev Ataması}

Gebze Nahiyesindeki vakıf eserinin türü ve cami veya mescidin bağlı olduğu yerleşim bakımından görevli kadrosu farklılık göstermektedir. Gebze nahiyesinde yer alan vakıf eserlerindeki cihetlere bakıldığında, İmam, Hatip, Müezzin, Mütevelli ${ }^{3}$, Cüzhan $^{4}$, Muallim-i Sıbyan (Mektep Hocası), Zaviyedar ${ }^{5}$, görevli kadrosunun bulunduğu görülmektedir.

\subsection{Görevlilerin Vazifeye Atanmaları}

Padişah berat ${ }^{6}$ ile ataması ile yapılan görevliler genelde kad 1 veya naip $^{7}$ az da olsa mütevelli arzı ile göreve getiriliyordu. Gebze vakıf eserlerinde, görevli cihetine çoğunlukla Gebze naibinin, 1710,1722 ve 1738 tarihli dört örnekte (V.G.M.A. HD. 1068/33- V.G.M.A. HD .1067/6- V.G.M.A. HD.1067/12) kadının, 1751 tarihli bir örnekte (V.G.M.A. HD. 1061/36) Üsküdar naibinin arzıyla atamanın gerçekleştiği görülmektedir.

\footnotetext{
${ }^{3}$ Bir vakfın idaresinde bulunan kişi (Develioğlu, 2007: 787).

${ }^{4}$ Namazlardan önce Kur'andan bir cüz okumakla sorumlu tutulan cami görevlisi (Pakalın, 1983:318).

${ }^{5}$ Zaviyelerde görevli küçük tekke şeyhi. (Pakalın, 1983: 648).

${ }^{6}$ Berat, memuriyet tayini, gelir tahsisi ya da bir imtiyaz ve kullanım hakk1 verilen Padişah tuğralı belgedir (Geniş bilgi için Kütükoğlu, 2018:124).

7 Naip, kadıların tayini ile kadı yardımcılığında bulunan, uzak yerleşimlerde yöneticilikte bulunan idari bir görevdir (Geniş bilgi için Tak, 2009: 39).
} 
1707 ve 1734'de Mehmed (V.G.M.A. HD. 1067/5., V.G.M.A. HD. 1068/29) 1751 ve 1752 'de Seyyid Yahya (V.G.M.A. HD. 1061/37., V.G.M.A. HD. 1061/38), 1734, 1747, 1748 ve 1785 'te Mehmed Emin Efendi (V.G.M.A. HD. 1060/4., V.G.M.A. HD.1061/34, V.G.M.A. HD. 1068/29), 1785'te Mehmed Said (V.G.M.A. HD. 1060/5), 1788'de Mehmed Hilmi (V.G.M.A. HD. 1060/5),1712, 1754 ve 1755 'te Ahmed (V.G.M.A. HD. 1061/40., V.G.M.A. HD. 1067/8., V.G.M.A. HD.1063/8), 1742'de İmamzâde Mehmet ve Osman (V.G.M.A. HD. 1061/29), 1743'te Sadik Mehmet (V.G.M.A. HD. 1061/29), 1758'de Çelebi Hasan V.G.M.A. HD. 1063/19), 1750'de Hüseyin Efendi (V.G.M.A. HD. 1061/36), 1750'de Feyzullah 1735'te Kıbrisi Mehmed (V.G.M.A. HD.1068/30), 1732'de Halil (V.G.M.A. HD. 1068/26), 1707 ve 1732 'de Lütfullah (V.G.M.A. HD. V.G.M.A. HD. 1067/5., 1068/26.), 1733 ve 1736'da Süleyman (V.G.M.A. HD. 1068/27., V.G.M.A. HD.1068/28., V.G.M.A. HD. 1068/31), 1737 ve 1738'de Abdülkerim (V.G.M.A. HD. 1068/33) ve 1709'da Seyyid Abdullah (V.G.M.A. HD. 1067/6) olmak üzere Gebze nahiyesindeki görevli naiplerdir.

1722'de İshak (V.G.M.A. HD. 1067/12) ve 1738'de Feyzullah Efendi (V.G.M.A. HD. 1068/33) Gebze'deki görev yapan kadılardır.

\subsection{Tevcihin Birden Fazla Kişi Üzerinde Olması}

Gebze nahiyesindeki vakıf eserlerinde görevler çoğunlukla tek kişi üzerinde iken bazı durumlarda bir görevin müşterek olarak yapıldığı görülmektedir. 1746 tarihinde Küçük Mescid'de imam olan Abdülkadir'in kasr-1 yed (kendi isteği doğrultusunda bırakma) etmesiyle Yahya ve Zekeriya halifelere imamet görevinde iştiraken tevliyet buyurulmuştur (V.G.M.A. HD. 1061/32). 1751 y1lında Zekeriya halifenin kardeşi Yahya'nın vefatıyla mahlulünden hissesi babası Hacı Hüseyin'e verilmiştir (V.G.M.A. HD. 1061/37).

757 tarihinde Hacı Hüseyin ve Yahya ortaklaşa imamlık görevinde iken, Hacı Hüseyin'in ölümüyle yarı hissesi oğlu Zekeriyya'ya verilmiştir (V.G.M.A. HD.1063/14). 1750 tarihinde Tuzla Köyü Camii vakfının mütevellisi Hacı Ahmet olup, oğlu Hafız Mustafa vakfın şart olarak koştuğu mektepte beratsız bir şekilde muallimlik yaptığı sırada İbrahim adında bir kimse kendi üzerine beraatı geçirmiştir. Lakin Hafız Mustafa ve babası durumu meclis-i şer'e haber vermeleriyle görev yeniden Hafız Mustafa'ya verilmiştir (V.G.M.A. HD.1061/39). 1754 tarihinde Timurcu Köyü Camii'nde imamlık görevini Abdülkerim ve kardeşi Mehmet ortaklaşa olarak yönetmişlerdir. 1757 tarihinde Abdülkerim yarı hissesini kendi isteği 
ile Seyyid Ali halifeye bırakarak feragat etmiştir (V.G.M.A. HD.1063/16).

\subsection{Cihetlerin Oğula veya Kardeșe Geçmesi}

Gebze nahiyesindeki görevlilerin vefat1, ref ya da ferağ durumunda görev hizmetinin genelde akraba yoluyla oğula ya da kardeşe geçtiği görülmektedir. Bila veled (çocuksuz) ya da liyâkata uyma durumlarında diğer kimselere de görev beratının verildiği anlaşılmaktadır.

1785 tarihinde Darıca Köyü Korucu Mehmed Mescidi'nde İmam olan Seyyid İbrahim'in ferağından oğlu Seyyid Mehmed'e berat verilmiştir (V.G.M.A. HD.1060/4). 1754 tarihinde Tavşancıl Köyü Camii’nde üç akçe ile müezzin olan Mehmed bin Mustafa'nın vefatı ile büyük oğlu Osman'a (V.G.M.A. HD.1061/40.) ve 1742 yılında Ferhad Sinan Ağa Mescidi'nde imam olan Abdurrahman'ın ölümü ile oğlu Hacı Hüseyin halifeye (V.G.M.A. HD.1061/29) arz buyurulmuştur. 1759 yılında Karabakkal Mescidi'nde imam olan Hafız Ahmed'in kendi rızasıyla fariğ olması nedeniyle oğlu İsmail halifeye tevcih buyurulmuştur (V.G.M.A. HD.1063/22). 1747 yılında Şeyhli Köyü Camii’nde imam ve hatip olan Ahmet'in ölümü ile oğlu Hasan halifeye tevcih buyurulmuştur (V.G.M.A. HD. 1061/34). 1734 yılında Pelitli Köyü Kethüda Mehmed Bey Camii'nde altı akçe ile imamlık görevinde bulunan Abbas'ın ölümüyle yerine oğlu Ali getirilmiștir (V.G.M.A. HD.1068/28). 1734 yılında Timurcular Köyü Camii'nde bir akçe ile imam olan İbrahim halifenin ölümüyle oğlu Mehmed halifeye (V.G.M.A. HD.1068/29), 1737 yılında Tavşanlı Köyü Camii'nde imam ve hatip İsmail'in vefatının ardından oğlu Mehmed halifeye (V.G.M.A. HD. 1068/33) arz buyurulmuş ve 1734 yılında Orhanlı Köyü Camii'nde imam ve hatip Mehmed bin Mustafa'nın beratı üzerinde olmakla feragat edip oğlu Seyyid Osman'a inayette bulunulmuştur (V.G.M.A. HD.1068/29).

Bila veled (çocuksuz) durumlarında görevlere başkalarının atandığı görülmektedir. 1788 'de Tavşancıl Köyü Camii'nde imam olan Mehmed bin Hüseyin'in vefatı ile Seyyid Mustafa bin Seyyid Osman'a (V.G.M.A. HD.1060/8), 1746 'da Ada Mescidi'nde imam olan Mehmed'in vefatı ile Ahmed halifeye (V.G.M.A. HD.1061/31), 1758 'de imam olan Ahmed halifenin vefatı ile Hasan bin Ahmed halifeye (V.G.M.A. HD.1063/19), 1746'da Küçük Mescid'de imam olan Yusuf' un vefatıyla Abdülkadir halifeye (V.G.M.A. HD.1061/32), 1738 'de Karabakkal Mescidi'nde imam olan Mehmed bin Abdullah vefatiyla Mehmed bin İbrahim'e (V.G.M.A. HD.1068/33), 1733 'te Denizli Köyü Camii'nde imam ve hatip olan Osman ibni İbrahim 
vefatıyla El-Hac Ahmed halife ibni Beşir'e (V.G.M.A. HD.1068/28), 1738 'de İlyas Bey Mescidi'nde iki akçe ile cüzhan olan Abdullah bin Mahmut'un vefatiyla Ahmed halife ibni Ömer'e (V.G.M.A. HD.1068/33), 1738'de Öksüzzade Muallimhanesi'nde iki akçe ile muallim-i sıbyan olan Abdullah bin Mahmut'un vefatıyla Ahmed halife ibni Ömer'e (V.G.M.A. HD.1068/33) görev verildiği örneklerden anlaşılmaktadır.

\subsection{Beratların Yenilenmesi veya Beratların Kaybedilmesi}

Beratlar bir padişahın saltanat süresince geçerli olup, padişah değişikliğinde vazife ve imtiyazların sürekliliği için yeni padişahın tuğrasıyla verilen berata "berat-1 tecdid" denilmektedir (Kütükoğlu, 2018: 136). Gebze nahiyesinde hurufat defterlerine göre birçok kayitta tecdid örneği görülmektedir. 1755'te Korucu Mehmed Mescidi'nde Mütevelli ve İmam (V.G.M.A. HD.1063/8), 1758'te İmam (V.G.M.A. HD. 1063/17), 1759'da mütevelli olan Seyyid Mustafa'nın (V.G.M.A. HD. 1063/22), 1758'de Tavşancil Köyü Camii'nde müezzin olan Mehmed bin Hüseyin halifenin berat-1 atik gereğince (V.G.M.A. HD.1063/18). 1755'te Tepecik Köyü Camii'nde imam ve hatip olan Seyyid Osman halifenin (V.G.M.A. HD.1063/12), 1757'de Tepecik köyü Camii'nde hasbi imam ve hatip olan Seyyid Osman halifenin (V.G.M.A. HD.1063/17), 1774'te hasbi imam ve hatip olan Mustafa bin Ahmed'in 1755 'te Karabakkal Mahallesi Mescidi'nde Mehmed'in kasr-1 yedinden İmam Hafiz Ahmed'in (V.G.M.A. HD. 1065/4), 1755 'te Pelitli Köyü Mehmed Kethüda Camii'nde imam olan Seyyid Hamza'nın (V.G.M.A. HD.1063/8), 1774'te ba muayyene imam hatip olan Ahmed bin Halil'in (V.G.M.A. HD.1065/4), 1731'de on akçe ile hatip olan Ali'nin (V.G.M.A. HD.1068/25), 1732'de altı akçe ile müceddeden imam olan Abbas halifenin (V.G.M.A. HD. 1068/26), 1758 'de Hereke Köyü Mektebi'nde muallim-i sıbyan olan Ahmed halifenin (V.G.M.A. HD.1063/19), 1703'te Hereke Köyü Camii'nde imam ve hatip olan Mustafa'nın (V.G.M.A. HD.1067/2), 1754'te Muallim Köyü Camii'nde hasbi imam ve hatip olan V.G.M.A. HD.1063/7), 1757'de hasbi imam ve hatip olan (V.G.M.A. HD.1063/16), 1774'te imam ve hatip olan Seyyid Hafiz Mustafa'nın (V.G.M.A. HD.1065/5), 1754'te Timurcu Köyü Camii'nde imam ve hatip olan Abdülkerim ve karındaşı Mehmed'in (V.G.M.A. HD.1063/7), 1755'te yarı imam ve hatip olan Mehmed'in (V.G.M.A. HD.1063/9), 1755'te Tavşanlı Köyü Camii'nde ba muayyene imam ve hatip olan Hüseyin'in (V.G.M.A. HD.1063/8), 1732'de ba muayyene imam Ahmed bin Ali'nin (V.G.M.A. HD.1068/25), 1774'te Orhanl Köyü Camii'nde ba muayyene imam ve hatip olan Ali bin Musa'nın 
(V.G.M.A. HD.1065/4), 1731'de ba muayyene imam ve hatip olan Mahmud bin İbrahim ferağından mutasarrıf Mehmed bin Mustafa'nın (V.G.M.A. HD.1068/24) ve 1711'de Haraçcı Bey Mescidi'nde imam İsmail'in (V.G.M.A. HD.1067/7) beratları tecdid edilmiştir.

Beratların kaybedilmesi durumunda sahibinin arzı üzerine ilgili kalemlere yapılan müracaat ile araştırma neticesinde yenisi verilmekteydi (Kütükoğlu, 2018:137). Gebze nahiyesinde 1707 y1lında Şeyhli/Şeyhlü Köyü Camii'nde bir akçe ile imam ve hatip olan Hüseyin'in (V.G.M.A. HD.1067/5), 1759 yılında Timurcular köyü Camii'nde imam ve hatip olan Seyyid Ali Ahmed'in (V.G.M.A. HD.1063/20) ve 1712 yilında Alanlar Zaviyesi'nde mütevelli olan imam Hüseyin'in (V.G.M.A. HD.1067/8) beratlarını kaybetmeleri nedeniyle yeni berat almışlardır.

\subsection{Mahallelinin Tercihiyle Atama}

Atamalardaki üç örnekte, mahallelinin tercihiyle göreve getirilmenin gerçekleştiği anlaşılmaktadır. Muallim Köyü Camii'nde 1752 yılında Hafiz Seyyid Mustafa (V.G.M.A. HD.1061/38), Pelitli Köyü Kethüda Mehmed Camii'nde 1748 yılında Ahmed halife (V.G.M.A. HD.1061/34) ve Orhanlı Köyü Camii'nde 1709 y1lında Mahmut (V.G.M.A. HD.1067/6) "muhtar-1 cemaat" (mahallelinin isteği) ile imam ve hatiplik kadrosuna getirilmiştir.

\section{6. Şeyhülislam İşareti ile Atama}

Hurufat defterlerine göre atama türlerinden birisi de Şeyhülislam işareti ile yapılan atamalardır. $\mathrm{Bu}$ tarz yapılan atamalarda genelde müderris ve vaiz görevlendirmeleri olmaktadır (Muşmal ve İnal 2015:121). Gebze nahiyesinde Kutbiddin Zaviyesinde 1785 tarihinde postnişin olan Seyyid Şeyh Abdullah'ın icrayı ayn eylemek üzere Gekboze naibi Mehmed Said ve Şeyhülislam Ahmed Ataullah Efendi hazretlerinin işaretleri ile ataması yapıldığı görülmektedir (V.G.M.A. HD.1060/5).

\subsection{Görevlinin İşinden Alınması}

Sözlükte lağvetme kaldırma anlamında olan (Develioğlu, 2004: 882) ref kelimesi, hurufat defterlerine göre görevden alma, işinden uzaklaştırma anlamlarında kullanılmıştır. Azl kelimesi ise doğrudan sözlükte işinden çıkarma anlamındadır (Develioğlu, 2004: 59). Örneklerimizde 4 kayıtta görevlinin görevinden uzaklaştırıldığı görülmektedir. Gebze nahiyesinde, 1755 yılında Tuzla Köyü Camii vakfinın akaratından olan menzilhanenin tevliyeti üzerinde olan İbrahim'in külli gadr etmekle (V.G.M.A. HD.1063/10), 1752 y1lında 
Muallim Köyü Camii'nde hasbi imam ve hatip olan Yahya'nın ahlak-1 zemime (kötü ahlak), menfur-1 cemaat ve serika töhmetiyle ve ortaya çıkmasından sonra firarı V.G.M.A. HD.1061/38), 1732 yılında Tavşanlı Köyü Camii'nde evkat-1 hamsede (beş vakit) imam olan Ahmed bin Ali'nin terk-i hizmet (V.G.M.A. HD.1068/26) ve 1709 y1lında Orhanlı Köyü Camii'nde imam ve hatip olan Osman'ın su-i hal (kötü durumu) (V.G.M.A. HD.1067/6) nedeniyle işlerinden alındığı anlaşılmaktadır.

\section{Sonuç}

Gebze Nahiyesi örnekleminde incelemeye tabi tutulmuş Hurufat Defterleri, 1060, 1061, 1063, 1065, 1067 ve 1068 nolu olmak üzere 6 adet defteri kapsamaktadır. Söz konusu defterler 1705-1789 tarihler arasındaki kayitlardan oluştuğu gözlenmektedir. İncelediğimiz Hurufat Defterleri, Gebze nahiyesinin sosyo kültürel ve iktisadi yönünü belirttiği gibi şehirdeki vakıf eserleri ve vakıf eserlerindeki idari yönetimi hakkında bilgi almamızı sağlayan önemli arşiv belgeleridir. Gebze nahiyesinde zaman içinde mahalle ve köy sayısında değişikliğe gidilmiş bazı köylerin nahiyeden ayrıldıkları anlaşılmaktadır. Yaptığımız incelemede 18.yy.'da Gebze nahiyesinde 20 adet cami, 8 adet mescit, 3 adet zaviye, 3 adet mektep ve 1 adet muallimhâne yapısının yer aldığı görülmektedir. İncelediğimiz 6 adet deftere göre vakıf eserlerinin daha dar bir zamana yayıldığı söylenebilir. Gebze nahiyesindeki vakıf eserlerinin bazısını hayır sahiplerinin yaptırdığı ayrıca sosyal ve ekonomik yönden vakıfların kurulduğu yaptığımız çalışmaya göre tespit edilmiştir. Vakıf eserlerinin büyük çoğunluğu camilerden oluşmaktaydı. Vakıf eserlerinin mescitler hariç daha çok köylerde konumladığı anlaşılmaktadır. Mescitler camilere oranla küçük çapta olup yoğun olarak mahallelerde inşa edilmiştir. Bazı mescitlerin zaman içinde artan talebe göre camiye dönüştürüldüğü görülmektedir. Vakıf eserlerinde görevli ataması ve çeşitliliğin en çok cami yapısında olduğu tespit edilmiştir. Görevler genelde babadan oğula geçmekle beraber, karındaş veya başka birisine de görev verilmekteydi. Bazı durumlarda mahallenin tercihi görevli tayininde etkiliydi. Zaviyelerde zaviyedar ve eğitim yapılarında ise muallim-i sıbyan görevli kadrosunun çoğunlukta olduğu görülmektedir. Kadı ve naipler tarafından atanan görevlilerin yanında, zaviyedeki cihet tayinlerinde Şeyhülislamın işareti de önemli bir etkendi. Görevlilerin nim akçe ile on akçe arasında ücretlendirildiği saptanmıştır. Görevlerde fevt, kasr-1 yed veya feragat neticesinde atamalar sağlanmıştır. Bazı durumlarda görevli işinden uzaklaştırılmıştır. 
Yapmış olduğumuz araştırmalar neticesinde 18.yy.'da Gebze nahiyesindeki vakıf eserlerinde çeşitliliği görmekteyiz. Yaptığımız araştırmalar sonucunda 18.yy.'da Gebze' de bulunan vakıf eserlerindeki 32 adet yapının günümüze gelemediği saptanmıștır. 2 adet yapıyı ise (Tuzla Köyü Camii ve Mektebi) günümüz İstanbul ili sınırları içerisinde kaldığı için araştırma fırsatı bulamadık. $\mathrm{Bu}$ nedenle günümüze ulaşıp ulaşamadığı hususunda bilgimiz bulunmamaktadır. Günümüzde Hereke'de yer alan Taş mektep ve Rüştiye mektebinin daha geç tarihli olduğu için defterde kaydı bulunan Hereke Köyü mektebi olmadığı anlaşılmıştır. Yukarı Hereke'de zamanında bir sıbyan mektebi bulunduğu (Galitekin, 2014: 158) arşiv kayıtlarında ifade edilmektedir. Söz konusu mektebin y1kılan bu mektep olduğunu söylemek mümkündür. Aynı şekilde günümüzde Hereke'nin merkezinde yer alan Hereke Sümer Camii'nin 19.yy. ortasında yapıldığı ve Dilovası ilçesi Tavşancıl'da bulunan iki caminin 18.yüzyıldan daha geç tarihli olduğu için defterde yer alan Hereke Köyü Camii ve Tavşancıl Köyü Camii yapılarının bu eserler olmadı̆̆ tarafımızca saptanmıştır. Gebze'deki Akçakoca'nın oğlu İlyas Bey tarafından yaptırılan (Çelik, 2003 :73) İlyas Bey Mescidi de orijinali yıkılarak yeniden betonarme olarak yapıldığ1 için tescilden düşmüş bulunmaktadır. Günümüzde Kandıra'da yer alan Araman Köyü Camii ise defterde geçen tek tescilli yapıdır. Araman'daki caminin ilk yapımı Orhan Gazi dönemine kadar uzanmaktadır (Ayverdi, 1966:123). Fakat yap1 birçok kez elden geçmiş ve bugünkü tescilli yap1 1950'li yıllarda yapılmıştır. İncelediğimiz defterlerde kaydı geçen Araman Köyü Camii'nin Orhan Gazi dönemindeki eser olduğunu söylemek mümkündür. Bunun dışında Gebze'de bulunan iki büyük yapı Üsküdar hurufat defterlerinin ele aldığımız kayıtlarında yer almamaktadır. Bunlardan biri Sultan Orhan Gazi Camii (14.yy.) diğeri ise Çoban Mustafa Paşa Külliyesidir (16.yy.). Günümüze kadar gelememiş olan yapıların depremler ve iklim koşulları neticesinde varlıklarını koruyamadıklarını söylemek mümkündür.

\section{Kaynakça \\ Yayınlar}

Alkan, M. (2010). Türk Vakıf Tarihi Araştırmaları Açısından Hurufat Defterleri: Adana Örneği. XV. Türk Tarih Kongresi Bildirileri Tam Metni içinde (s. 825-842), 4 (1). Ankara: Türk Tarih Tarih Kurumu. 
Ayverdi, E. H. (1966). İstanbul Mimari Çağın Menşe'i Osmanl Mimarisinin Ilk Devri 630-805 (1230-1402). İstanbul: Baha Matbaası

Baykara, T. (1990). Osmanlı Taşra Teşkilatında XVIII. Yüzyılda Görev ve Görevliler (Anadolu). Ankara: Vakıflar Genel Müdürlüğü Yayınları.

Beyazit, Y. (2013). Hurufat Defterlerinin Şehir Tarihi Araştırmalarındaki Yeri. History Studies, 5 (1), 39-69.

Çakar, E., Uzun, C. (2017). Hurufat Defterlerinde Harput (1690-1812). Elazığ: Fırat Üniversitesi Harput Uygulama ve Araştırma Merkezi Yayınları.

Çakar, E. (2018). Hurufat Defterlerine Göre 18. Yüzyılda Palu. Vakıflar Dergisi, (49), 21-41.

Çal, H. (2001). Hurufat Defterlerine Göre 19. Yüzyılda Küre Kazası. Prof. Dr. Zafer Bayburtluoğlu Armağanı Sanat Yazıları, 125-166.

Çelik, G. (2003). 16.-19.yy. Gebze (Sosyo-Ekonomik Bir İnceleme), Gebze: Gebze Belediyesi Kültür Yayınları.

Demirtaş, H. (2012). Vakıf Araştırmalarında Kaynak Olarak Hurûfat Defterleri: Kangırı Örneği. Vakıflar Dergisi, (37), 47-92.

Develioğlu, F. (2004). Osmanlıca-Türkçe Ansiklopedik Lügat. (ss.59,658,787,882) Ankara: Aydın Kitabevi Yayınları.

Erpolat, S.M. (2015). XVI. Yüzyıldan XX. Yüzyıla Kocaeli'ndeki Yer Adlarında Meydana Gelen Değişmeler. Uluslararası Gazi Akçakoca Sempozyum Bildirileri Tam Metni içinde (s. 497-535), C.1. Kocaeli: Kocaeli Belediyesi Yayınları.

Galitekin, A. N. (2014). Tarihte Kocaeli Körfez İlçesi. Kocaeli: Körfez Belediyesi Kültür Yayınları.

Gökmen, E. (2005). Hurufat Defterlerine Göre Demirci Kazası ve Köylerinde Cami ve Mescitler (1690-1830). Celal Bayar Üniversitesi Sosyal Bilimler Dergisi, 3 (2), 21-56.

Kaya, M. (2007). XIX. Yüzyılda İzmit (Kocaeli) Sancağı'nın Demografik Durumu ve İskân Siyaseti. A.Ü. Tarih Araştırmaları Dergisi, 26(41), 59-80.

Kütükoğlu, M. (2018). Osmanlı Belgelerinin Dili (Diplomatik). Ankara: Türk Tarih Kurumu.

Memiş Eroğlu, Ş. (2016). Hurufat ya da Askeri Ruznamçe Defterlerinde Yer Alan Vakıf Kurumu Dışındaki Atamaların Kazâ-yı Kudüs-i Şerif Örneğinde İncelenmesi. OTAM, (39), 75104.

Muşmal, H. ve İnal, S. (2015). Hurufat Defterlerinin Şehir Tarihi Araştırmalarındaki Yeri. 3. Milletlerarası Şehir Tarihi Yazarları 
Kongresi Bildirileri Tam Metin içinde (s. 119-129). Şanlıurfa: Türkiye Yazarlar Birliği.

Naldan, F. (2018). Hurufat Defterlerine Göre 19. Yüzyılın İlk Çeyreğinde Kemah Kazasında Türk Mimarisi. Inönü Üniversitesi Kültür ve Sanat Dergisi, (4) 1, 85-95.

Naldan, F. (2020). Hurufat Defterlerine Göre 17. ve 18. Yüzy1llarda Gercanis'de (Refahiye) Bulunan Vakıf Eserler. Vakıflar Dergisi, (53), 115-131.

Ocak, A. Y. ve Faruki, S. (1986). Zaviye. Íslam Ansiklopedisi içinde (Cilt.13, ss. 468-476) İstanbul: Milli Eğitim Basımevi.

Öntuğ, M. M. (1999). Hurufat Defterlerine Göre Uşak’taki Eğitim Müesseseleri (1702-1824). Afyon Kocatepe Üniversitesi Sosyal Bilimler Dergisi, (3), 149-272.

Pakalın, M. Z. (1983). Osmanlı Tarih Terimleri ve Deyimleri Sözlüğü. İstanbul: Milli Eğitim Basımevi.

Tak, E. (2009). Diplomatik Bilimi Bakımından XVI.-XVII. Yüzyıl Kadı Sicilleri ve Bu Sicillerin Ihtiva Ettiği Belge Türlerinin Form Özellikleri ve Tanımlanması. (Yayınlanmamış Yüksek Lisans Tezi). Marmara Üniversitesi/Türkiyat Araştırmaları Enstitüsü, İstanbul.

Turgut, V. (2015). XVI. Yüzyılın Sonlarında Kocaeli Sancağı'nda Demografik ve İktisadi Vaziyet. Uluslararası Gazi Akçakoca Sempozyum Bildirileri Tam Metni içinde (s.337-439), C.1. Kocaeli: Kocaeli Belediyesi Yayınları.

Yıldız, P. (2010). Hurufat Defterlerine Göre Maraş Kazası. (Yayınlanmamış Yüksek Lisans Tezi). Selçuk Üniversitesi/Eğitim Bilimleri Enstitüsü, Konya.

Yurdakul, İ. (2016). Gebze Nahiyesi'ne bağlı Vakıf Karyeler. Uluslararasi Karamürsel Alp ve Kocaeli Tarihi Sempozyumu-II Bildirilei Tam Metni içinde (s.1225-1254), C.2. Kocaeli: Kocaeli Belediyesi Yayınları.

Yücel, E. (2018). Gebze (Dakibza). R. Orman (Ed.), Kitalarl Buluşturan Tarihsel Geçiş Hattı Üzerinde Bir Kent: Gebze (s. 4958). İstanbul: Gebze Belediyesi Kültür Yayınları.

\section{İnternet Kaynakları}

https://www.uskudar.bel.tr/tr/main/erehber/tekkeler/12/ibrahim-agacamii-tekkesi. 


\section{Arşivler}

Vakıflar Genel Müdürlüğü (Hurufat Defterleri)
V.G.M.A. HD. 1060/ H.1190 (M.1776)- H.1203 (M.1788).
V.G.M.A. HD. 1061/ H.1155 (M.1742)- H.1168 (M.1754).
V.G.M.A. HD. 1063/ H.1168 (M.1754)- H. 1173 (M.1759).
V.G.M.A. HD. 1065/ H.1188 (M.1774)- H.1189 (M.1775).
V.G.M.A. HD. 1067/ H.1116 (M.1705)- H.1135 (M.1722).
V.G.M.A. HD. 1068/ H.1143 (M.1731)- H.1151 (M.1738).

\section{EK Tablo 1:}

\begin{tabular}{|c|c|c|c|c|c|c|}
\hline $\begin{array}{l}\text { Sir } \\
\text { a } \\
\text { No }\end{array}$ & $\begin{array}{l}\text { Köyü İsmi } \\
\text { (Hurufat } \\
\text { Defterlerinde } \\
\text {-18.yy.) }\end{array}$ & $\begin{array}{l}\text { 16. yy. } \\
\text { (TADB.TT } \\
\text { D.49 N'olu } \\
\text { Kayit- } \\
\text { Muhasebe- } \\
\text { i Vilayeti } \\
\text { Anadolu } \\
\text { Defteri) }\end{array}$ & $\begin{array}{l}\text { 17.yy. }{ }^{9} \\
\text { (TADB. } \\
\text { TTD.579 } \\
\text { No'lu } \\
\text { Kayit) }\end{array}$ & $\begin{array}{l}19 . y y . \\
10 \\
\text { (B.A. } \\
\text { Temett } \\
\text { uat } \\
\text { Defterl } \\
\text { eri } \\
3584- \\
3615)\end{array}$ & $\begin{array}{l}\text { 20.yy. } \\
\text { Baş1 } 11 \\
\text { (Defter-i } \\
\text { Hümayu } \\
\text { n- } \\
\text { Muhase } \\
\text { be-i } \\
\text { Vilayeti } \\
\text { Anadolu } \\
\text { Defteri } \\
\text { vs.) }\end{array}$ & $\begin{array}{l}\text { Günümüzdeki } \\
\text { Durumu }\end{array}$ \\
\hline 1 & Darıca & Darıcı & Darıca & Darıca & & $\begin{array}{l}\text { Bu köy, } \\
\text { günümüzde } \\
\text { Kocaeli İli'nin } \\
\text { bir ilçesi } \\
\text { durumundadır. }\end{array}$ \\
\hline 2 & Akviran & Akviran & Akviran & & Akviran & Mollafenari \\
\hline 3 & Nerdibanlı & $\begin{array}{l}\text { Nerdubanl } \\
\mathrm{u}\end{array}$ & $\begin{array}{l}\text { Merdibanl } \\
\mathrm{u}\end{array}$ & & & $\begin{array}{l}\text { Bu köy, } \\
\text { günümüzde } \\
\text { Kadıköy ilçesine } \\
\text { bağlı bir } \\
\text { mahalledir. } \\
\text { Günümüzde } \\
\text { Merdivenköy } \\
\text { olarak } \\
\text { bilinmektedir. }\end{array}$ \\
\hline 4 & Tavşancıl & & & $\begin{array}{l}\text { Tavşan } \\
\text { c1l }\end{array}$ & & $\begin{array}{l}\text { Bu köy, } \\
\text { günümüzde } \\
\text { Dilovası İlçesi'ne } \\
\text { bağlı bir } \\
\text { mahalledir. }\end{array}$ \\
\hline
\end{tabular}

8 Turgut, 2015: 405-418; Çelik, 2003,15; Erpolat, 2015: 522-527.

${ }^{9}$ Yurdakul, 2016: 1235-1236.

${ }^{10}$ Çelik, 2003: 88.

${ }^{11}$ Çelik, 2003: 15. 


\begin{tabular}{|c|c|c|c|c|c|c|}
\hline 5 & $\begin{array}{l}\text { Tepecik/Dep } \\
\text { ecik }\end{array}$ & $\begin{array}{l}\text { Söğüdcük } \\
\text { Nam-1 } \\
\text { Diğer } \\
\text { Depecik }\end{array}$ & $\begin{array}{l}\text { Söğütcük } \\
\text { Nam-1 } \\
\text { Diğer } \\
\text { Tepecik }\end{array}$ & $\begin{array}{l}\text { Tepeci } \\
\mathrm{k}\end{array}$ & & $\begin{array}{ll}\text { Bu } & \text { köy, } \\
\text { günümüzde } \\
\text { Dilovası } & \text { ilçe } \\
\text { sınırlarında } & \\
\text { kalmaktadır. } & \end{array}$ \\
\hline 6 & Meşeler? & & & & & \\
\hline 7 & Şeyhler & & & & & $\begin{array}{l}\text { Bu } \\
\text { günümüzde } \\
\text { Sakarya } \\
\text { sinırları içinde } \\
\text { olup, } \\
\text { sonunda } \\
\begin{array}{l}\text { Kandıra'ya bağlı. } \\
\text { bir nahiye idi? }\end{array}\end{array}$ \\
\hline 8 & $\begin{array}{l}\text { Şeyhli/Şeyhl } \\
\ddot{u}\end{array}$ & Şeyhlü & & & & $\begin{array}{l}\text { Bu köry } \\
\text { günümüzde, } \\
\text { Pendik İlçesi } \\
\text { sinırları } \\
\text { içerisindedir } \\
\end{array}$ \\
\hline 9 & Pelitli & Pelidlü & Pelidlü & Pelitli & Pelidli & Pelitli \\
\hline 10 & Tuzla & $\begin{array}{l}\text { Tekye } \\
\text { Nam-1 } \\
\text { Diğer } \\
\text { Tuzla Köyü }\end{array}$ & $\begin{array}{l}\text { Nikide } \\
\text { Nam-1 } \\
\text { Diğer } \\
\text { Tuzla }\end{array}$ & Tuzla & & $\begin{array}{l}\text { Bu köy, } \\
\text { günümüzde } \\
\text { İstanbul'a bağl1 } \\
\text { bir ilçedir. }\end{array}$ \\
\hline 11 & Hereke & $\begin{array}{l}\text { Hereke } \\
\text { ma'a } \\
\text { Gezerli } \\
\text { Köyü }\end{array}$ & $\begin{array}{l}\text { Hereke } \\
\text { ma'a } \\
\text { Gezerli }\end{array}$ & Hereke & Hereke & $\begin{array}{l}\text { Bu kü köy, } \\
\text { günümüzde } \\
\text { Körfez İlçesi'ne } \\
\text { bağll bir belde } \\
\text { statüsündedir. }\end{array}$ \\
\hline 12 & Muallim & & & & Muallim & Muallim \\
\hline 13 & $\begin{array}{l}\text { Timurcular/ } \\
\text { Timurcu }\end{array}$ & $\begin{array}{l}\text { Demürciler } \\
\text { /Demircülü }\end{array}$ & $\begin{array}{l}\text { Demircül } \\
\ddot{u ̈}\end{array}$ & $\begin{array}{l}\text { Demirc } \\
\text { iler }\end{array}$ & & Demirciler \\
\hline 14 & $\begin{array}{l}\text { Tavşan/Tavş } \\
\text { anlı/Tavşanl } \\
\text { u }\end{array}$ & $\begin{array}{l}\text { Tavşanli/T } \\
\text { avşanlu }\end{array}$ & Tavşanlu & $\begin{array}{l}\text { Tavşan } \\
l_{1}\end{array}$ & Tavşanlı & Tavşanlı \\
\hline 15 & $\begin{array}{l}\text { Orhan/Orhan } \\
\text { l1 Köyü }\end{array}$ & Orhanlu & Orhanlu & $\begin{array}{l}\text { Orhane } \\
\text { li? }\end{array}$ & Orhanlı & Orhanlı \\
\hline 16 & Araman & $\begin{array}{l}\text { Arman } \\
\text { (Kandıra } \\
\text { Nahiyesi } \\
\text { dahilinde } \\
\text { gösterilme } \\
\text { ktedir) }\end{array}$ & - & - & - & $\begin{array}{l}\text { Bu kö̈y, } \\
\text { günümüzde } \\
\text { Kandıra ilçe } \\
\text { sinırlarında } \\
\text { kalmaktadır. } \\
\text { Günümüzde } \\
\text { Kaymaz olarak } \\
\text { da bilinmektedir. }\end{array}$ \\
\hline 17 & $\begin{array}{l}\text { Cunkara } \\
\text { Nam-1 Diğer } \\
\text { Cuma }\end{array}$ & Çonkara & Conk? & $\begin{array}{l}\text { Cumalı } \\
?\end{array}$ & & Cumaköy? \\
\hline 18 & Karaaliler & $\begin{array}{l}\text { Ada Beylü } \\
\text { Nam-1 } \\
\text { Diğer Kara } \\
\text { Ali Köyü }\end{array}$ & $\begin{array}{l}\text { Ada } \\
\text { Beylü } \\
\text { Nam-1 } \\
\text { Diğer } \\
\text { Kara Ali } \\
\text { Köyü } \\
\end{array}$ & & $\begin{array}{l}\text { Karaca } \\
\text { Ali? }\end{array}$ & $\begin{array}{l}\text { Günümüzde } \\
\text { böyle bir köy } \\
\text { bulunmamaktadı } \\
\text { r. }\end{array}$ \\
\hline 19 & Cumalı & & & Cumali & & Cumaköy \\
\hline
\end{tabular}




\begin{tabular}{|c|c|c|c|c|c|c|}
\hline 20 & Denizli & $\begin{array}{l}\text { Donuzluca } \\
?\end{array}$ & $\begin{array}{l}\text { Tonuzluc } \\
\text { a? }\end{array}$ & Denizli & Denizli & Denizli \\
\hline 21 & $\begin{array}{l}\text { Bollu Dede } \\
\text { Köyü? }\end{array}$ & $\begin{array}{l}\text { Bollu } \\
\text { Köyü? } \\
\text { (Karasu } \\
\text { Nahiyesi } \\
\text { sinırlarında } \\
\text { gösterilme } \\
\text { ktedir) }\end{array}$ & & & & $\begin{array}{l}\text { Günümüzde } \\
\text { böyle bir köy } \\
\text { bulunmamaktadı } \\
\text { r. }\end{array}$ \\
\hline 22 & $\begin{array}{l}\text { Sinanlı/Sina } \\
\text { nlar }\end{array}$ & $\begin{array}{l}\text { Sinanlu } \\
\text { (Kandıra } \\
\text { Nahiyesi } \\
\text { sinırlarında } \\
\text { gösterilme } \\
\text { ktedir) } \\
\end{array}$ & & & & $\begin{array}{l}\text { Günümüzde } \\
\text { böyle bir köy } \\
\text { bulunmamaktadı } \\
\text { r. }\end{array}$ \\
\hline 23 & $\begin{array}{l}\text { Çerkeşli/Çer } \\
\text { keşlü }\end{array}$ & Çerkeşlü & Çerkeşli & $\begin{array}{l}\text { Çerkeşl } \\
\mathrm{i}\end{array}$ & & $\begin{array}{ll}\begin{array}{l}\text { Bu } \\
\text { günümüzde }\end{array} & \text { köy, } \\
\text { Dilovas1 } & \text { ilçe } \\
\text { sinırları } & \\
\text { içerisinde } & \text { yer } \\
\text { almaktadır. } & \\
\end{array}$ \\
\hline
\end{tabular}

\section{EK Tablo 2:}

\begin{tabular}{|c|c|c|c|c|c|}
\hline $\begin{array}{l}\text { Sira } \\
\text { No }\end{array}$ & $\begin{array}{l}\text { Mahalle İsmi } \\
\text { (Hurufat } \\
\text { Defterlerinde- } \\
\text { 18.yy.) }\end{array}$ & $\begin{array}{l}\text { 16.yy/ (436- } \\
116-438 \text { No'lu } \\
\text { Tahrir } \\
\text { Defterleri/ B.A. } \\
\text { Temettuat } \\
\text { Defterleri/ } \\
\text { TADB.TTD.49 } \\
\text { N'olu Kayit }{ }^{12}\end{array}$ & $\begin{array}{l}\text { 17.yy. } \\
\text { TADB.TTD. } \\
49 \quad \text { N'olu } \\
\text { Kayit }^{13}\end{array}$ & $\begin{array}{l}\text { 19.yy. } \\
\text { B.A. Temettuat } \\
\text { Defterleri, } 438 \\
\text { No'lu Tahrir } \\
\text { Defterleri }{ }^{14}\end{array}$ & Günümüz \\
\hline 1 & Ferhad Sinan & & & & $\begin{array}{l}\text { Günümüzd } \\
\text { e böyle bir } \\
\text { mahalle } \\
\text { bulunmama } \\
\text { ktadır. }\end{array}$ \\
\hline 2 & Ada & Adalı & Adalı & Ada & $\begin{array}{l}\text { Günümüzd } \\
\text { e böyle bir } \\
\text { mahalle } \\
\text { bulunmama } \\
\text { ktadır. }\end{array}$ \\
\hline 3 & Karabakkal & Karabakkal & Karabakkal & Karabakkal & $\begin{array}{l}\text { Günümüzd } \\
\text { e böyle bir } \\
\text { mahalle } \\
\text { bulunmama } \\
\text { ktadır. }\end{array}$ \\
\hline 4 & $\begin{array}{l}\text { Mehter Sinan } \\
\text { Mahallesi }\end{array}$ & & & & $\begin{array}{l}\text { Günümüzd } \\
\text { e böyle bir } \\
\text { mahalle } \\
\text { bulunmama } \\
\text { ktadır. }\end{array}$ \\
\hline
\end{tabular}

${ }^{12}$ Erpolat, 2015: 498-499; Çelik, 2003:122; Turgut, 2015: 347.

${ }^{13}$ Yurdakul, 2016:1235.

${ }^{14}$ Çelik, 2003:122. 


\begin{tabular}{|l|l|l|l|l|l|}
\hline 5 & $\begin{array}{l}\text { Güzeller } \\
\text { Mahallesi }\end{array}$ & $\begin{array}{l}\text { Güzel nam-1 } \\
\text { diğer Haraçc1 }\end{array}$ & $\begin{array}{l}\text { Güzel nam-1 } \\
\text { diğer } \\
\text { Haraçc1 }\end{array}$ & Güzel & Güzeller \\
\hline
\end{tabular}

\section{Ek Tablo 3:}

\begin{tabular}{|c|c|c|c|c|}
\hline Yer Adı & Cami Adı & $\begin{array}{l}\text { Caminin } \\
\text { Defterdeki } \\
\text { Tarih Aralığ1 }\end{array}$ & $\begin{array}{lr}\text { Cami } & \text { Vakfi } \\
\text { Cihetleri }{ }^{15} \text { ve } \\
\text { Bu Cihetlere } \\
\text { Yapılan } & \text { Atama } \\
\text { ve } & \text { Tecdid } \\
\text { Sayısı } & \\
\end{array}$ & $\begin{array}{l}\text { Hurufat Defter } \\
\text { ve Sayfa } \\
\text { Numaralar1 }\end{array}$ \\
\hline Akviran Köyü & $\begin{array}{l}\text { Akviran Köyü } \\
\text { Camii }\end{array}$ & $1721-1785$ & $\begin{array}{l}\text { 1/İmam } \\
\text { 1/Hatip }\end{array}$ & $\begin{array}{l}1060 / 4 \\
1067 / 12\end{array}$ \\
\hline Tavşancıl Köyü & $\begin{array}{l}\text { Tavşancıl } \\
\text { Köyü Camii }\end{array}$ & $1754-1788$ & $\begin{array}{l}\text { 1/Müezzin } \\
1 / \text { İmam }\end{array}$ & $\begin{array}{l}1060 / 8 \\
1061 / 40 .\end{array}$ \\
\hline Tepecik Köyü & $\begin{array}{l}\text { Tepecik Köyü } \\
\text { Camii }\end{array}$ & $1742-1774$ & $\begin{array}{l}\text { 1/Hatip } \\
\text { 2/İmam-Hatip }\end{array}$ & $\begin{array}{l}1061 / 29-39 \\
1063 / 12-17 \\
1065 / 4 .\end{array}$ \\
\hline Şeyhler Köyü & $\begin{array}{l}\text { Şeyhler Köyü } \\
\text { Camii }\end{array}$ & $1743-1758$ & 2/İmam-Hatip & $\begin{array}{l}1061 / 30 \\
1063 / 18 \\
\end{array}$ \\
\hline $\begin{array}{l}\text { Şeyhli/Şeyhlu } \\
\text { Köyü }\end{array}$ & $\begin{array}{l}\text { Şeyhli Köyü } \\
\text { Camii }\end{array}$ & $1706-1751$ & 4/İmam-Hatip & $\begin{array}{l}1061 / 34-36 \\
1067 / 4-5 .\end{array}$ \\
\hline Pelitli Köyü & $\begin{array}{l}\text { Kethüda } \\
\text { Mehmed Camii }\end{array}$ & $1731-1774$ & $\begin{array}{l}\text { 1/Hatip } \\
\text { 4/İmam } \\
\text { 1/Müezzin } \\
\text { 3/İmam Hatip }\end{array}$ & $\begin{array}{l}1061 / 34-36 \\
1063 / 8-10 \\
1065 / 4 \\
1068 / 25-26-28\end{array}$ \\
\hline Tuzla Köyü & $\begin{array}{ll}\text { Tuzla } & \text { Köyü } \\
\text { Camii } & \\
\end{array}$ & 1755 & 1/İmam & $1063 / 10$ \\
\hline Hereke Köyü & $\begin{array}{l}\text { Hereke Köyü } \\
\text { Camii }\end{array}$ & $1703-1759$ & $\begin{array}{l}\text { 1/Hatip } \\
\text { 1/İmam-Hatip }\end{array}$ & $\begin{array}{l}1063 / 23 \\
1067 / 2\end{array}$ \\
\hline Muallim Köyü & $\begin{array}{l}\text { Muallim Köyü } \\
\text { Camii }\end{array}$ & $1735-1774$ & 5/İmam-Hatip & $\begin{array}{l}1061 / 38 \\
1063 / 7-16 \\
1065 / 5 \\
1068 / 30-32 \\
\end{array}$ \\
\hline $\begin{array}{l}\text { Timurcular } \\
\text { (Demirciler) } \\
\text { Köyü }\end{array}$ & $\begin{array}{l}\text { Timurcular } \\
\text { Köyü Camii }\end{array}$ & $1710-1775$ & $\begin{array}{l}\text { 7/İmam-Hatip } \\
\text { 1/Hatip }\end{array}$ & $\begin{array}{l}1061 / 39 \\
1063 / 7-9-16-20 \\
1065 / 6 \\
1067 / 6 \\
1068 / 29\end{array}$ \\
\hline Tavşanlı Köyü & $\begin{array}{l}\text { Tavşanlı Köyü } \\
\text { Camii }\end{array}$ & $1722-1775$ & $\begin{array}{l}\text { 3/İmam } \\
\text { 6/İmam-Hatip } \\
\text { 1/Mütevelli } \\
\text { 1/Hatip }\end{array}$ & $\begin{array}{l}1061 / 40 \\
1063 / 8-19 \\
1065 / 6 \\
1067 / 12 \\
1068 / 25-26-27- \\
29-33-34\end{array}$ \\
\hline
\end{tabular}

${ }^{15}$ Defterde bulunan cami için kaç atama olduğu ve sonrasında görevlileri belirtmektedir. 


\begin{tabular}{|c|c|c|c|c|}
\hline Araman Köyü & $\begin{array}{l}\text { Araman Köyü } \\
\text { Camii }\end{array}$ & 1754 & 1/İmam-Hatip & $1061 / 40$ \\
\hline $\begin{array}{l}\text { Orhanlı Köyü } \\
\text { Camii }\end{array}$ & $\begin{array}{l}\text { Orhanlı Köyü } \\
\text { Camii }\end{array}$ & $1705-1774$ & 1/İmam-Hatip & $\begin{array}{l}1065 / 4 \\
1067 / 3-6 \\
1068 / 24-29-31- \\
33\end{array}$ \\
\hline Çunkara Köyü & $\begin{array}{l}\text { Fenari Ahmed } \\
\text { Paşa Camii }\end{array}$ & $1705-1708$ & 3/İmam Hatip & $1067 / 3-4-5$ \\
\hline Çerkeşli Köyü & $\begin{array}{l}\text { Çerkeşli Köyü } \\
\text { Camii }\end{array}$ & $1707-1722$ & $\begin{array}{l}\text { 1/İmam-Hatip } \\
\text { 2/Müezzin }\end{array}$ & $1067 / 5-9-13$ \\
\hline Karaaliler Köyü & $\begin{array}{l}\text { Ali bin Hüseyin } \\
\text { Camii }\end{array}$ & 1708 & 1/Mütevelli & $1067 / 5$ \\
\hline Cumalı Köyü & $\begin{array}{l}\text { Cumalı Köyü } \\
\text { Camii }\end{array}$ & $1709-1712$ & 1/İmam-Hatip & $1067 / 6-8$ \\
\hline Denizli Köyü & $\begin{array}{l}\text { Denizli Köyü } \\
\text { Camii }\end{array}$ & $1711-1733$ & 2/İmam-Hatip & $\begin{array}{l}1067 / 8 \\
1068 / 28\end{array}$ \\
\hline $\begin{array}{l}\text { Kurşun Madeni } \\
\text { Yakınında Bollu } \\
\text { Dede Köyü }\end{array}$ & $\begin{array}{l}\text { Bollu Dede } \\
\text { Köyü Camii }\end{array}$ & 1722 & $\begin{array}{l}\text { 1/Müezzin- } \\
\text { 1/İmam }\end{array}$ & $1067 / 13$ \\
\hline $\begin{array}{ll}\text { Mehter } & \text { Sinan } \\
\text { Mahallesi } & \\
\end{array}$ & $\begin{array}{l}\text { Mehter Sinan } \\
\text { Camii }\end{array}$ & 1746 & $1 /$ İmam & $1061 / 33$ \\
\hline
\end{tabular}

\section{Ek Tablo 4:}

\begin{tabular}{|c|c|c|c|c|}
\hline Yer Adı & Mescit Ad1 & $\begin{array}{l}\text { Mescidin } \\
\text { Defterdeki } \\
\text { Tarih Aralığı }\end{array}$ & $\begin{array}{lr}\text { Mescit Vakfi } \\
\text { Cihetleri }{ }^{16} \text { ve } \\
\text { Bu Cihetlere } \\
\text { Yapılan Atama } \\
\text { ve } & \text { Tecdid } \\
\text { Sayısı } & \\
\end{array}$ & $\begin{array}{ll}\text { Hurufat } & \text { Defter } \\
\text { ve } & \text { Sayfa } \\
\text { Numaraları }\end{array}$ \\
\hline Darıca Köyü & $\begin{array}{l}\text { Korucu } \\
\text { Mehmed } \\
\text { Mescidi }\end{array}$ & $1707-1785$ & $\begin{array}{l}\text { 5/İmam } \\
\text { 3/Mütevelli }\end{array}$ & $\begin{array}{l}1060 / 4 \\
1061 / 37-39 \\
1063 / 8-17-22, \\
1067 / 2\end{array}$ \\
\hline Tepecik Köyü & $\begin{array}{l}\text { Tepecik Köyü } \\
\text { Mescidi }\end{array}$ & $1720-1742$ & $2 /$ İmam & $\begin{array}{l}1061 / 29 \\
1067 / 11\end{array}$ \\
\hline $\begin{array}{l}\text { Ferhad Sinan } \\
\text { Mahallesi }\end{array}$ & $\begin{array}{l}\text { Ferhad Sinan } \\
\text { Ağa Mescidi }\end{array}$ & 1742 & $2 /$ İmam & $1061 / 29$ \\
\hline Ada Mahallesi & Ada Mescidi & $1712-1758$ & 3/İmam & $\begin{array}{l}1061 / 31 \\
1063 / 19 \\
1067 / 8 \\
\end{array}$ \\
\hline $\begin{array}{l}\text { Karabakkal } \\
\text { Mahallesi }\end{array}$ & $\begin{array}{l}\text { Karabakkal } \\
\text { Mescidi }\end{array}$ & $1738-1759$ & 5/İmam & $\begin{array}{l}1061 / 32 \\
1063 / 8-22 \\
1068 / 33\end{array}$ \\
\hline $\begin{array}{l}\text { Güzeller } \\
\text { Mahallesi }\end{array}$ & $\begin{array}{ll}\text { Haraçc1 } & \text { Bey } \\
\text { Mescidi } & \\
\end{array}$ & 1711 & 1/İmam & $1067 / 7$ \\
\hline $\begin{array}{l}\text { Gekboze } \\
\text { Kasabası }\end{array}$ & Küçük Mescid & $1746-1757$ & 4/İmam & $\begin{array}{l}1061 / 32-37 \\
1063 / 14\end{array}$ \\
\hline
\end{tabular}

${ }^{16}$ Defterde bulunan cami için kaç atama olduğu ve sonrasında görevlileri belirtmektedir. 


\begin{tabular}{|c|c|c|c|}
\hline $\begin{array}{l}\text { Gekboze } \\
\text { Kasabası }\end{array}$ & $\begin{array}{ll}\text { İlyas } & \text { Bey } \\
\text { Mescidi } & \end{array}$ & $1737-1738$ & $\begin{array}{l}\text { 1/Cüzhan } \\
\text { 1/Mütevelli }\end{array}$ \\
\hline
\end{tabular}

EK Tablo 5:

\begin{tabular}{|c|c|c|c|c|}
\hline Yer Adı & Yap1 Ad1 & $\begin{array}{l}\text { Yapının } \\
\text { Defterdeki } \\
\text { Tarih Aralığı }\end{array}$ & $\begin{array}{lr}\text { Yapı } & \text { Vakfi } \\
\text { Cihetleri }^{17} \text { ve } \\
\text { Bu Cihetlere } \\
\text { Yapılan } \\
\text { ve Atama } \\
\text { Sayısı }\end{array}$ & $\begin{array}{l}\text { Hurufat Defter } \\
\text { ve } \quad \text { Sayfa } \\
\text { Numaraları }\end{array}$ \\
\hline $\begin{array}{l}\text { Karabakkal } \\
\text { Mahallesi }\end{array}$ & $\begin{array}{l}\text { Karabakkal } \\
\text { Mahallesi } \\
\text { Mektebi }\end{array}$ & 1755 & $\begin{array}{l}\text { 1/Mektep } \\
\text { Hocas1-İmam }\end{array}$ & $1063 / 8$ \\
\hline Tuzla Köyü & $\begin{array}{ll}\text { Tuzla } & \text { Köyü } \\
\text { Mektebi } & \\
\end{array}$ & 1750 & $\begin{array}{l}\text { 1/Muallim-i } \\
\text { Sibyan }\end{array}$ & $1061 / 36$ \\
\hline Hereke Köyü & $\begin{array}{ll}\text { Hereke } & \text { Köyü } \\
\text { Mektebi } & \\
\end{array}$ & $1752-1758$ & $\begin{array}{l}\text { 1/Muallim-i } \\
\text { Sibyan }\end{array}$ & $\begin{array}{l}1061 / 38 \\
1061 / 19\end{array}$ \\
\hline Gekboze & $\begin{array}{l}\text { Öksüzzade } \\
\text { Muallimhânesi }\end{array}$ & 1738 & $\begin{array}{l}\text { 1/Muallim-i } \\
\text { Sibyan }\end{array}$ & $1068 / 33$ \\
\hline
\end{tabular}

\section{Ek Tablo 6:}

\begin{tabular}{|l|l|l|l|l|}
\hline Yer Adı & Cami Adı & $\begin{array}{l}\text { Caminin } \\
\text { Defterdeki } \\
\text { Tarih Aralığı }\end{array}$ & $\begin{array}{l}\text { Cami Vakfi } \\
\text { Cihetleri }^{18} \text { ve Bu } \\
\text { Cihetlere } \\
\text { Yapılan Atama } \\
\text { ve Tecdid Sayıs }\end{array}$ & $\begin{array}{l}\text { Hurufat Defter } \\
\text { ve Sayfa } \\
\text { Numaraları }\end{array}$ \\
\hline Sinanlar Köyü & $\begin{array}{l}\text { Alanlar } \\
\text { Zaviyesi }\end{array}$ & $1712-1714$ & $\begin{array}{l}1 / \text { Mütevelli } \\
1 / \text { Zaviyedar }\end{array}$ & $1067 / 8$ \\
\hline $\begin{array}{l}\text { Gekboze } \\
\text { Kasabası }\end{array}$ & $\begin{array}{l}\text { Kutbuddin } \\
\text { Zaviyesi }\end{array}$ & 1785 & $\begin{array}{l}1 / \text { Zaviyedar- } \\
\text { Mütevelli }\end{array}$ & $1060 / 8$ \\
\hline $\begin{array}{l}\text { Nerdibanlı } \\
\text { Nerdübanlı) } \\
\text { Köyü }\end{array}$ & $\begin{array}{l}\text { İbrahim Ağa } \\
\text { Zaviyesi }\end{array}$ & 1788 & & \\
\hline
\end{tabular}

${ }^{17}$ Defterde bulunan cami için kaç atama olduğu ve sonrasında görevlileri belirtmektedir.

18 Defterde bulunan cami için kaç atama olduğu ve sonrasında görevlileri belirtmektedir. 


\section{EK Harita 1:}
K A R A
$D E N \mid Z$

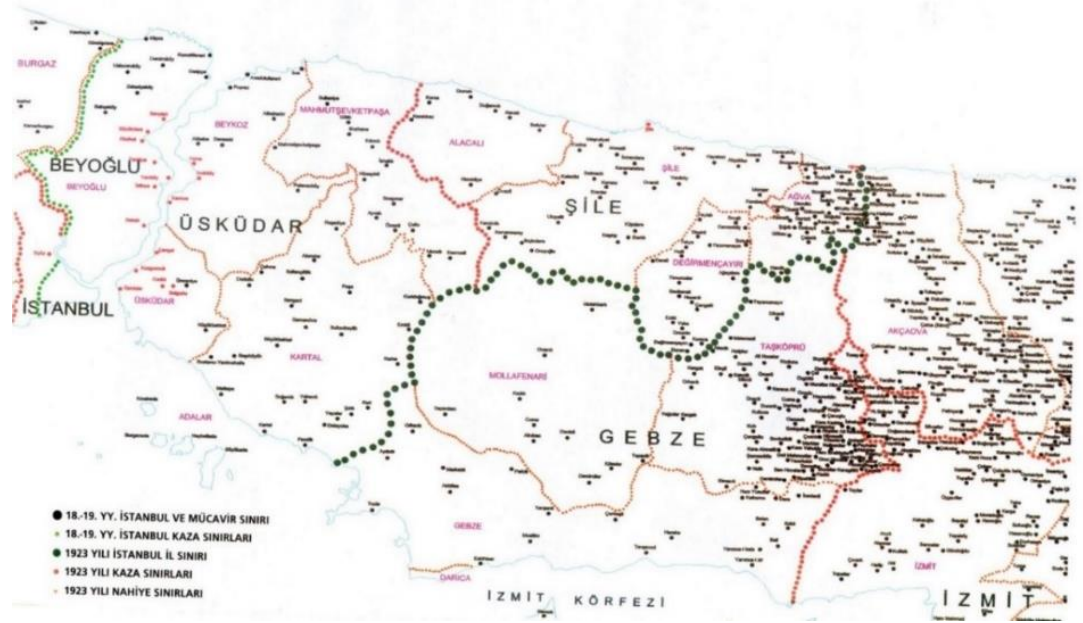

Harita 1: Gebze Nahiyesi Haritası (18 ve 20.yy. Yüzylllar) (Çelik, 2003.) 


\section{EK Resim 1:}

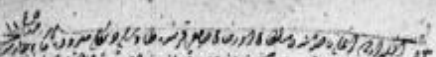

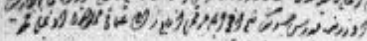

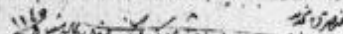

is

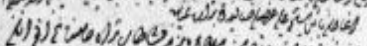

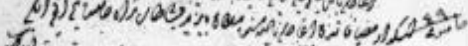

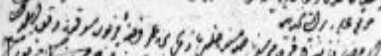

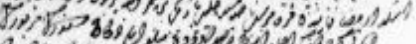

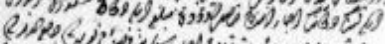

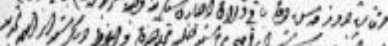

(1)

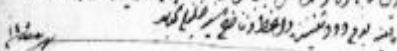

16

0

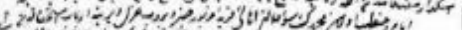

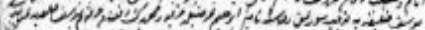

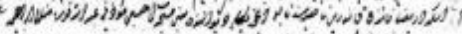

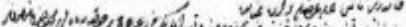

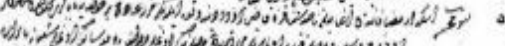

Wir

is)

6. . . .

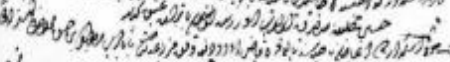

Q

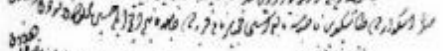

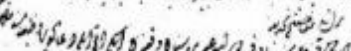

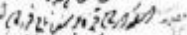

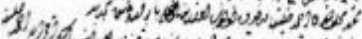

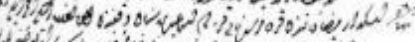
$66^{\circ}$

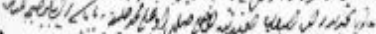

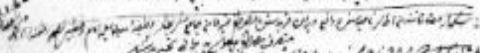

(18)

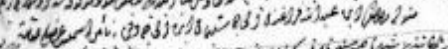

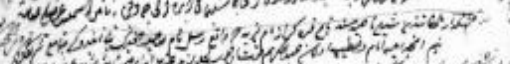

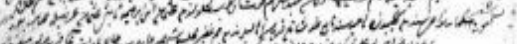

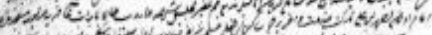

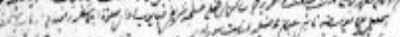

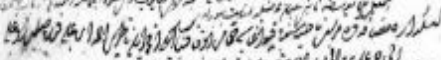

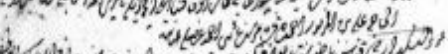

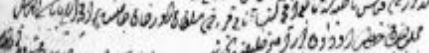

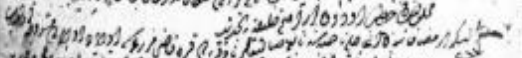

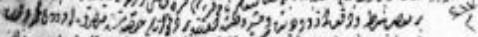

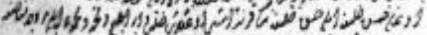

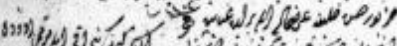

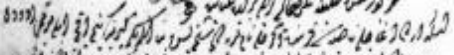

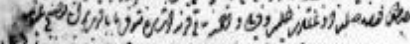

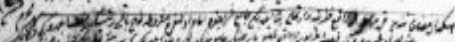

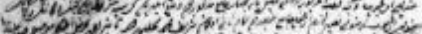

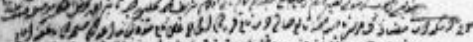

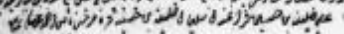

\section{7}

Resim 1: Gebze Nahiyesi ile İlgili Üsküdar Hurufat Defteri Kayıt Örneği (V.G.M.A. HD. 1068/2)
113239 c. (1) s

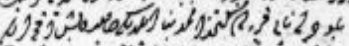
110

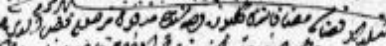

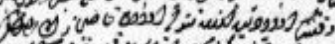
بر فi

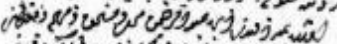

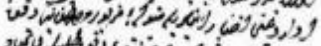

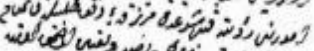

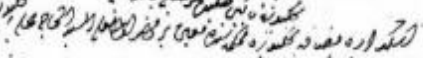

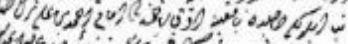
مان का

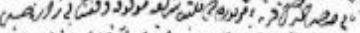

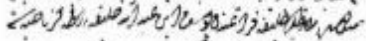

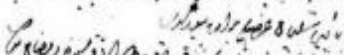
ه(e)

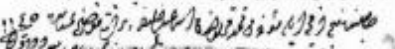

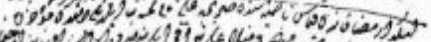

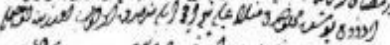

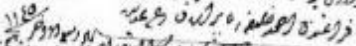

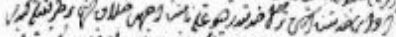

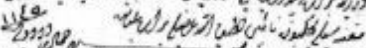

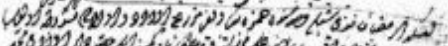

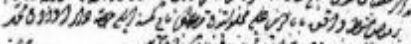

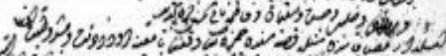

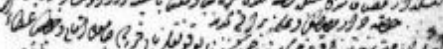

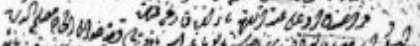

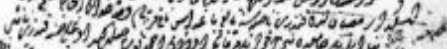

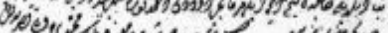

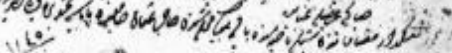

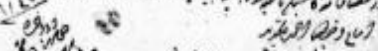

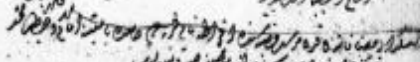

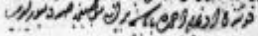

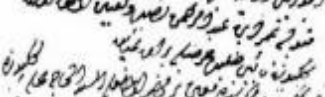

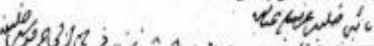

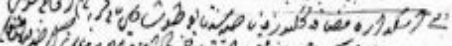

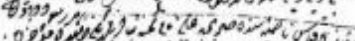

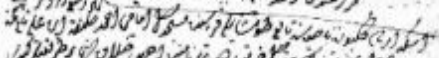

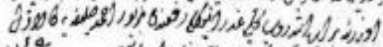
ad dive

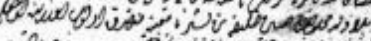

